\title{
Pengembangan Model Jenjang Karir Perawat Klinis di Unit Rawat Inap Rumah Sakit
}

\section{Clinical Nursing Career Model Development in Inpatient Units of Hospital}

\author{
Febi Kornela $K^{1}$, Tatong Hariyanto ${ }^{2}$, Arhwinda Pusparahaju ${ }^{3}$ \\ ${ }^{1}$ Fakultas Kesehatan Masyarakat Universitas Sam Ratulangi Manado \\ ${ }^{2}$ Program Studi Magister Manajemen Rumah Sakit Fakultas Kedokteran Universitas Brawijaya Malang \\ ${ }^{3}$ Rumah Sakit Baptis Batu Malang
}

\begin{abstract}
ABSTRAK
Perawat klinik di RSBB terdiri dari pegawai tetap dan pegawai kontrak. Pengembangan karir yang selama ini dilaksanakan di RSBB berdasarkan masa kerja dan pelatihan yang diikuti oleh perawat belum dilaksanakan sesuai dengan jenjang karir profesional perawat. Penelitian ini bertujuan untuk menganalisa pengembangan karir perawat klinik di rumah sakit Baptis Batu (RSBB) dan menyusun rancangan pengembangan karir profesional perawat di rumah sakit Baptis Batu. Penelitian ini merupakan penelitian kualitatif. Penelitian dilakukan selama bulan Oktober-November 2013. Data diperoleh dengan wawancara dan focus group discussion (FGD) dengan Direktur rumah sakit, manajer sumber daya manusia, kepala komite keperawatan, manajer keperawatan, kepala-kepala ruangan dan perwakilan perawat di unit rawat inap. Hasil penelitian menunjukkan sebagian besar perawat $(96,7 \%)$ memiliki latar belakang pendidikan DIII keperawatan, belum terdapat pola khusus dalam pelaksanaan recruitment, rotasi dan promosi perawat. Rancangan jenjang karir profesional perawat di RSBB disusun berdasarkan latar belakang pendidikan, masa kerja dan uji kompetensi. Dari setiap level jenjang karir, perawat akan dibagi dalam kategori perawat junior, middle dan senior dan diikuti dengan pemberian penghargaan berupa remunerasi.
\end{abstract}

Kata Kunci: Pengembangan karir, perawat klinik

\section{ABSTRACT}

Clinical nurses in Baptis Hospital Batu consist of permanent and contract employees. Career development carried out in Baptis Hospital Batu was based on years of service and training followed by nurses and has not been conducted in accordance with professional nursing career. This study aims to analyze the development of clinical nursing career in Baptis Hospital Batu. This research is qualitative. The research was conducted from October to November 2013. Data were obtained through interviews and focus group discussion (FGD) with the hospital director, human resources managers, nursing committee chief, nursing managers, the heads of the room and the nurse representative on inpatient units. The results show that the majority of nurses (96,7\%) had an educational background of DIII nursing, yet there is a special pattern in the implementation of recruitment, rotation and promotion of nurses. The design of nurses' professional career in Baptis Hospital Batu is set based on educational background, years of service and competency tests. Of every career level, the nurses will be divided into categories of junior, middle and senior nurses and respected with award in the form of remuneration.

Keywords: Career development, clinical nurse

Jurnal Kedokteran Brawijaya, Vol. 28, Suplemen No. 1 2014: Febi Kornela K. Fakultas Kesehatan Masyarakat Universitas Sam Ratulangi Manado, Jl. Kampus Kleak, Manado, Sulawesi Utara95115 Tel. (0431)827129Email:febikornela@gmail.com 


\section{PENDAHULUAN}

Untuk menghadapi persaingan pelayanan kesehatan antar negara dan kemajuan teknologi maka rumah sakit harus meningkatkan kualitas pelayanan termasuk diantaranya kualitas sumber daya manusia (SDM). Perawat merupakan salah satu sumber daya penting di rumah sakit dan merupakan salah satu kunci keberhasilan pelayanan di rumah sakit hal ini dikarenakan perawat merupakan sumber daya terbanyak di rumah sakit dan yang berinteraksi lebih banyak dengan pasien. Dalam memberikan pelayanan keperawatan, perawat sebagai tenaga profesional harus memberikan pelayanan sesuai dengan kompetensi dan kewenangan yang dimiliki baik secara individu maupun sebagai bagian dari suatu tim $(1,2)$. Keperawatan merupakan satu bentuk pelayanan atau asuhan yang bersifat humanistic, professional dan holistic berdasarkan ilmu dan kiat serta memiliki standar asuhan dan menggunakan kode etik yang dilandasi oleh profesionalisme yang mandiri atau kolaborasi (3).

Perawat berperan dalam mencapai tujuan rumah sakit yaitu menuju pada rumah sakit bertaraf internasional dengan menerapkan pelayanan profesional dan pelayanan bermutu. Untuk mencapai tujuan tersebut maka diperlukan perawat yang kompeten, memberikan pelayanan yang aman kepada pasien dan sesuai dengan kode etik profesi. Salah satu cara untuk meningkatkan mutu pelayanan adalah dengan adanya pengembangan karir perawat. Jenjang karir merupakan pengakuan terhadap pengalaman, keahlian dan kinerja dari perawat, juga merupakan suatu kesempatan bagi perawat untuk mengembangkan kinerja dan profesionalismenya sesuai dengan kompetensi yang ada.

Profesi merupakan suatu pekerjaan yang memerlukan pendidikan dan berhubungan dengan ketrampilan intelektual. Profesi adalah pekerjaan yang ditujukan untuk kepentingan masyarakat sedangkan profesional adalah seseorang yang berkompeten dalam pekerjaan tertentu (4). Tenaga profesional yang berkompeten memahami akan keterbatasan mereka, mampu secara mandiri memberikan perawatan yang aman sesuai dengan tanggung jawab yang ditetapkan standar profesi serta pendidikan dan kualifikasi. Bekerja bersama dalam tim, menghargai peran dan sudut pandang dari rekan kerja, memiliki pandangan kedepan dan mampu merespon situasi baik yang direncanakan maupun tak direncanakan $(5,6)$.

Tidak dilaksanakannya jenjang karir perawat di rumah sakit akan memberikan dampak pada tingkat kepuasan perawat di rumah sakit dan akan mempengaruhi motivasi kerja perawat (7). Perawat merasa bahwa kinerja mereka tidak dihargai dan hal ini cenderung membuat perawat meninggalkan rumah sakit (turnover). Kurangnya perawat yang memadai dan kompeten dalam pelayanan keperawatan dapat memberikan dampak negatif terhadap rumah sakit berupa: menurunnya kualitas pelayanan kepada pasien, meningkatkan resiko terjadinya kejadian yang tidak diinginkan yang juga berdampak pada bertambahnya waktu perawatan dan meningkatnya biaya perawatan pasien, jumlah pasien akan berkurang, berkurangnya pendapatan rumah sakit dan meningkatnya biaya yang harus dikeluarkan oleh rumah sakit $(2,7-9)$. Saat ini pengembangan jenjang karir perawat sudah dikembangkan akan tetapi belum sepenuhnya berbasis kompetensi. Beberapa sarana kesehatan sudah mulai mengembangkan pengembangan jenjang karir profesional akan tetapi masih kurang memperhatikan tuntutan dan kebutuhan profesi dan belum dihubungkan dengan sistem penghargaan.

Dari data kepegawaian Agustus 2013 perawat di RS Baptis Batu (RSBB) berjumlah 73 orang yang terdiri dari D4/S1 keperawatan 2 orang $(2,73)$, D III 70 orang $(95,9 \%)$ dan SPK 1 orang $(1,36 \%)$. Dari keseluruhan perawat yang ada di RS Baptis Batu, unit rawat inap memiliki jumlah perawat terbanyak yaitu sebanyak 30 orang atau hampir $50 \%$ dari keseluruhan perawat yang ada di RS Baptis Batu. Pengembangan karir perawat di rumah sakit Baptis Batu belum dilaksanakan berdasarkan kompetensi. Komite keperawatan rumah sakit Baptis Batu belum memiliki bagian SDM khusus keperawatan yang merumuskan halhal yang berhubungan dengan SDM keperawatan dan tim khusus yang bertanggung jawab dalam pengembangan karir perawat, juga perawat pelaksana belum memahami dan mengetahui manfaat dari adanya jenjang karir. Hal ini sejalan dengan penelitian yang menunjukkan $52 \%$ perawat pelaksana menyatakan belum memahami tentang sistem pengembangan karir (10). Kajian ini dilakukan untuk mengembangkan model pengembangan karir perawat klinik sebagai bagian dari proses manajemen pengembangan sumberdaya manusia.

\section{METODE}

Penelitian ini dilakukan dengan menganalisis pengembangan karir yang sedang dilaksanakan di RSBB dan merancang model pengembangan karir perawat sesuai dengan pendidikan, masa kerja dan kompetensi perawat. Penelitian dilakukan di RSBB sejak bulan oktober sampai November 2013. Data dikumpulkan dengan menggunakan metode telaah dokumen, wawancara dengan Direktur, bagian SDM, komite keperawatan dan manajer keperawatan juga dilakukan focus group discussion ( $F G D$ ) dengan pimpinan rumah sakit, bagian SDM, komite keperawatan, manajer keperawatan dan kepala-kepala unit/ruangan dan perwakilan dari perawat di unit rawat inap. Metode FGD dilakukan sebanyak dua kali. Fokus dari diskusi pertama adalah membahas rancangan konsep jenjang karir perawat yang akan dibuat dan fokus diskusi kedua adalah mendiskusikan hasil rancangan jenjang karir perawat yang sudah dibuat.

\section{HASIL}

Penelitian didahului dengan studi pendahuluan yaitu mengidentifikasi SDM yang ada di RSBB kemudian dilanjutkan dengan mengidentifikasi sistem sistem jenjang karir yang sedang dilaksanakan dan menyusun model rancangan jenjang karir.

\section{Gambaran Ketenagaan Perawat di RSBB}

Jumlah keseluruhan tenaga perawat di RSBB berjumlah 73 orang dan tenaga perawat yang berada di unit rawat inap berjumlah 30 orang (41\% dari keseluruhan perawat yang ada). Tabel 1 adalah jumlah perawat di unit rawat inap berdasarkan status kepegawaian.

Dari keseluruhan perawat di unit rawat inap 21 orang (70\%) bersatatus sebagai pegawai tetap, 5 orang $(16,7 \%)$ calon pegawai dan 4 orang $(13,3 \%)$ pegawai kontrak. Berdasarkan status kepegawaian, sebagian besar perawat di unit rawat inap berstatus sebagai pegawai tetap. Berdasarkan tingkat pendidikan dan pelatihan, jumlah perawat yang memiliki latar belakang pendidikan D III 29 
orang $(96,7 \%)$, D4/S1 1 orang $(3,3)$ sedangkan pelatihan yang sudah diikuti oleh perawat adalah pelatihan basic life support (BLS) sebayak 27 orang (90\%) dan pelatihan manajemen bangsal sebanyak 2 orang $(6,6 \%)$. Berdasarkan pedoman jenjang karir profesional perawat yang ditetapkan oleh DEPKES RI tahun 2006, kualifikasi tenaga profesional dimulai dari lulusan D III keperawatan. Tingkat pendidikan perawat di RSBB sudah memenuhi syarat untuk pengembangan jenjang karir.

Berdasarkan masa kerja perawat di unit rawat inap, perawat dengan masa kerja 0-2 tahun berjumlah 15 orang (50\%), 2-5 tahun 6 orang (20\%), 5-9 tahun 0 dan lebih dari 9 tahun 9 orang (30\%). Tabel 1 menunjukkan jumlah perawat di unit rawat inap berdasarkan masa kerja. Berdasarkan Tabel 1 sebagian besar perawat memiliki masa kerja dibawah 2 tahun sebanyak 15 orang atau $50 \%$ dari keseluruhan perawat di unit rawat inap.

Tabel 1. Jumlah pegawai di unit rawat inap

\begin{tabular}{lclccc}
\hline \multicolumn{2}{c}{ Status Kepegawaian } & \multicolumn{2}{c}{ Tingkat Pendidikan } & \multicolumn{2}{c}{ Masa Kerja } \\
\hline \multicolumn{1}{c}{ Status } & Jumlah & Pendidikan & Jurnlah & $\begin{array}{c}\text { Masa } \\
\text { Kerja }\end{array}$ & Jumlah \\
\hline Pegawai tetap & 21 & D III & 29 & $0-2$ tahun & 15 \\
$\begin{array}{l}\text { Calon Pegawai } \\
\text { Tetap }\end{array}$ & 5 & D IV/S I & 1 & $2-5$ tahun & 6 \\
$\begin{array}{l}\text { Pegawai } \\
\text { Kontrak }\end{array}$ & 4 & & & $>9$ tahun & 9 \\
Total & 30 & Tcital & 30 & Total & 30 \\
\hline
\end{tabular}

\section{Pengembangan Karir Perawat di RSBB}

RSBB saat ini belum memiliki pola atau perencanaan khusus dalam penjenjangan karir. Rekruitmen perawat dilakukan pada saat terjadi kekosongan perawat di RS. Rekruitmen dilakukan oleh bagian SDM. RSBB terkadang mengalami kesulitan dalam rekruitmen perawat disebabkan kurangnya perawat yang mendaftarkan diri di RSBB. Informasi tentang rekruitmen perawat dilakukan dengan cara mengirimkan surat atau pemberitahuan ke institusi pendidikan disekitar RSBB.

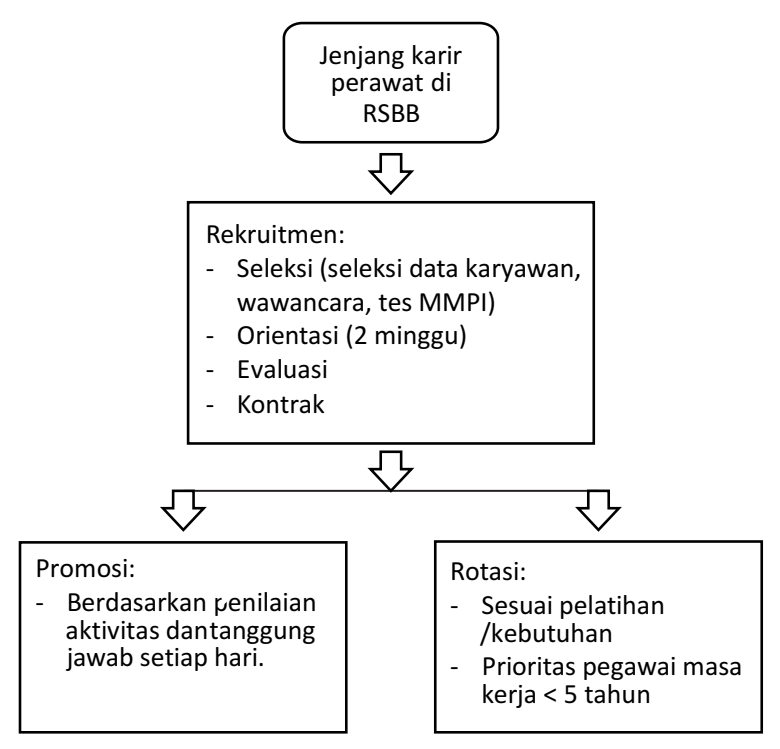

Gambar 1. Jenjang karir yang dilaksanakan di RSBB
Dalam pelaksanaan proses rekruitmen, seleksi dilakukan melalui wawancara yang dilakukan oleh bagian SDM, komite keperawatan dan wadir pelayanan kemudian dilanjutkan dengan tes psikologi menggunakan MMPI yang dilakukan oleh dokter spesialis kesehatan jiwa dan tahap terakhir adalah tes kesehatan. Setelah lulus seleksi perawat harus melalui masa orientasi. Masa orientasi berlangsung selama 2 minggu. Tujuan dari masa orientasi ini adalah untuk memperkenalkan suasana kerja di RSBB juga untuk melatih perawat khususnya yang baru memulai karirnya sebagai perawat. Setelah masa orientasi perawat akan dievaluasi dan akan melaksanakan kontrak dengan RSBB (Gambar 1).

Rotasi perawat di RSBB dilakukan sesuai dengan kebutuhan perawat di tiap-tiap unit dan juga sesuai dengan pelatihan atau kompetensi perawat. Perawat yang dirotasi adalah perawat dengan masa kerja dibawah 5 tahun dengan pertimbangan bahwa perawat dengan masa kerja lebih dari 5 tahun sudah memiliki banyak pengalaman di unit atau ruangan dan sudah sangat dipercaya menjadi penanggungjawab shift.

Promosi jabatan merupakan salah satu penghargaan yang diberikan kepada perawat atas kinerja perawat. Promosi perawat di RSBB dilakukan berdasarkan penilaian seharihari terhadap aktivitas perawat termasuk tanggungjawabnya dalam melaksanakan pekerjaan. Promosi jabatan berdasarkan uji kompetensi belum dilakukan dikarenakan komite keperawatan belum memiliki tim khusus yang bertanggungjawab untuk pelaksanaan uji kompetensi. RSBB belum memiliki prosedur khusus dalam melakukan promosi jabatan perawat.

Rancangan Model Pengembangan Jenjang Karir Perawat $\operatorname{diRSBB}$

Penjenjangan karir professional perawat terdiri dari 4 bidang meliputi perawat klinik (PK), perawat manajer (PM), perawat pendidik (PP) dan perawat peneliti/riset (PR). Berdasarkan hasil FGD rancangan jenjang karir perawat disusun mengacu pada pedoman jenjang karir profesional perawat yang ditetapkan oleh Direktorat Pelayanan Keperawatan Departemen Kesehatan RI tahun 2006. Dalam penyusunan model jenjang karir perawat di RSBB hanya difokuskan pada perawat klinik dan perawat manajer hal ini didasarkan pada hasil diskusi dan telaah dokumen dimana perawat diunit rawat inap masih tergolong dalam perawat klinik dan perawat manajer.Berdasarkan pedoman jenjang karir professional perawat yang ditetapkan oleh DEPKES, perawat klinik terdiri dari: perawat klinik I (PK I), perawat klinik II (PK II), perawat klinik III (PK III), perawat klinik IV (PK IV) dan perawat klinik V (PK V). (Lampiran).

Dalam penentuan level jenjang karir perawat ada beberapa tahapan yang harus dilakukan. Tahap pertama adalah seleksi administrasi. Pada tahap ini perawat akan diseleksi berdasarkan pendidikan dan masa kerja kemudian masuk dalam tahap berikutnya yaitu uji kompetensi yang terdiri dari uji kompetensi tulisan dan praktek. Tahap akhir adalah penentuan level perawat berdasarkan seleksi administrasi dan uji kompetensi. Pada setiap level, perawat klinik akan dibagi dalam kategori perawat junior, middle, dan senior sesuai dengan hasil pencapaian uji kompetensi, pengkategorian ini dilakukan untuk memudahkan pihak manajemen dalam pemberian remunerasi. Setiap perawat akan menempati level sesuai 
dengan seleksi administrasi dan kompetensi dan akan meningkat pada level selanjutnya sesuai dengan kompetensi yang ada (Lampiran).

Level jenjang karir perawat klinik di RSBB terdiri dari 5 level yaitu dimulai dari perawat klinik I sampai V. Pada saat perawat diterima sebagai pegawai di RSBB, perawat tersebut akan mengikuti masa orientasi dan dimasukkan dalam kategori asosiasi perawat kemudian setelah melewati masa orientasi perawat tersebut akan masuk dalam tahapan penentuan level jenjang karir. Perawat akan memulai karirnya sesuai dengan tingkat pendidikan dan kompetensi. Perawat klinik II (PK II) bisa melanjutkan ke perawat klinik III (PK III) dan bisa juga menempati level perawat manajer I (PM I). Perawat klinik III juga bisa menjadi perawat manajer I (PM I). Perawat klinik III (PK III) yang memiliki latar belakang pendidikan diploma III jika ingin melanjutkan karir ke perawat klinik IV (PK IV) harus melanjutkan pendidikan ke diploma IV/ sarjana keperawatan. Dalam pengelompokan perawat ke setiap level jenjang karir, perawat akan dibagi dalam kategori perawat junior, middle dan senior sesuai dengan hasil uji kompetensi yang akan diikuti dengan pemberian penghargaan berupa remunerasi.

\section{DISKUSI}

Dalam pelayanan keperawatan, perawat sebagai tenaga profesional bertanggungjawab memberikan pelayanan sesuai dengan kompetensi dan kewenangan yang dimiliki. Pasien dengan berbagai masalah kesehatan sangat menggantungkan kehidupannya pada ketrampilan profesional dan perawatan dari perawat (10).

Dari latar belakang pendidikan perawat yang ada di RSBB hampir seluruhnya memiliki latar belakang pendidikan D III keperawatan dan bagian SDM belum memiliki rancangan pengembangan pendidikan dan pelatihan staf. Rumah sakit harus melakukan pengembangan karir perawat baik lewat pendidikan formal ke jenjang yang lebih tinggi maupun pendidikan non formal yaitu dengan pelatihan-pelatihan. Pekerjaan sebagai perawat menuntut tanggungjawab yang besar. Tantangan akan menjadi bagian perawat dalam melaksanakan karirnya oleh karena itu menghadapi berbagai macam tantangan dan untuk meningkatkan kualitas dan keamanan sistem layanan kesehatan maka perawat harus mempersiapkan diri dengan pendidikan, pelatihan dan pengalaman sesuai dengan kompetensinya. Pendidikan merupakan suatu proses untuk mengembangkan kemampuan karyawan sedangkan pelatihan merupakan bagian dari pendidikan $(1,5,11)$.

Pengembangan karir perawat di RSBB dilakukan berdasarkan kebutuhan saat itu dan bersifat situasional, belum terdapat pola atau pattern dalam penjenjangan karir terutama dalam rekruitmen dan promosi perawat. Sistem jenjang karir professional perawat memuat tiga aspek yang saling berhubungan yaitu kinerja, orientasi profesional dan kepribadian perawat, serta kompetensi yang menghasilkan kinerja professional. Komponen utama karir terdiri dari alur karir, tujuan karir, perencanaan karir dan pengembangan karir. Pencapaian karir seseorang tidak hanya ditentukan oleh sistem karir yang ditetapkan oleh organisasi akan tetapi ditentukan juga oleh keinginan individu/perawat itu sendiri untuk mencapai karirnya hal ini sesuai dengan teori Davis dan Werther yang menguraikan lima faktor terkait dengan karir meliputi: keadilan dalam karir, perhatian dengan penyeliaan, kesadaran tentang kesempatan, minat pekerja dan kepuasan karir (10).

Pengembangan jenjang karir profesional perawat pada setiap bidang harus berjenjang dan bersifat terbuka dimana perawat profesional dimungkinkan mencapai jenjang karir disemua bidang. Pengembangan karir yang dilakukan di RSBB sampai saat ini dilakukan berdasarkan pendidikan, masa kerja, penilaian kinerja dan pelatihan yang sudah diikuti oleh perawat, belum dilakukan berdasarkan uji kompetensi yang ada. Uji kompetensi sangat diperlukan dalam penentuan level jenjang karir karena dengan uji kompetensi dapat diketahui apakah seseorang layak menempati level itu atau tidak. Dengan adanya kompetensi tersebut maka perawat diharapkan dapat mengerjakan dan mengatur tugas yang diberikan, dapat mengambil keputusan dalam melaksanakan pekerjaan, dapat bekerja sama dengan sesama rekan kerja dan anggota tim dan akan berusaha untuk terus mengembangkan pengetahuan dan ketrampilannya (12).

Sistem jenjang karir menuntut manajemen rumah sakit untuk mengembangkan jenjang karir di rumah sakit juga cara untuk mencapai jenjang karir tersebut. Dengan adanya sistem jenjang karir akan memberikan dampak positif tidak hanya untuk manajemen akan tetapi untuk perawat itu sendiri. Dengan adanya sistem jenjang karir dapat merubah moral perawat lewat kepuasan kerja dari pekerjaan yang dia lakukan dan akan mendorong perawat untuk terus meningkatkan pengetahuan dan keahliannya sesuai dengan bidangnya. Bagi manajemen rumah sakit dengan adanya sistem jenjang karir dapat memberikan penghargaan kepada perawat lewat tugas kerja mereka baik penghargaan finansial maupun promosi jabatan, memudahkan dalam melakukan rotasi dan mutasi perawat juga memberikan pengakuan dari profesi lain kepada perawat akan peran dan wewenang perawat di rumah sakit (10). Untuk mencapai sistem jenjang karir profesional perawat maka sikap, pengetahuan dan ketrampilan perawat harus ditingkatkan sesuai dengan kompetensinya. Pihak rumah sakit harus mengupayakan adanya pendidikan dan pelatihan berkesinambungan bagi perawat dan didukung dengan adanya penghargaan baik pengakuan atas hasil kerja, promosi jabatan maupun dalam bentuk finansial.untuk memotivasi perawat dan memberikan kepuasan kerja bagi perawat (13-15).

Jenjang karir di Rumah Sakit Baptis Batu meliputi rekruitmen, seleksi, orientasi rotasi dan promosi. Promosi karir perawat dilakukan berdasarkan penilaian aktivitas perawat sehari-hari, belum dilaksanakan sesuai kompetensi perawat. Model rancangan jenjang karir professional perawat klinik di RSBB terdiri dari 5 level yaitu perawat klinik I (PK I), perawat klinik II (PK II), perawat klinik III (PK III), perawat klinik IV (PK IV) dan perawat klinik V (PK V). Penentuan level jenjang karir dilakukan berdasarkan pendidikan, masa kerja dan uji kompetensi. Setiap level jenjang karir akan dibagi dalam kategori junior, middle dan senior berdasarkan hasil uji kompetensi dan akan diberikan remunerasi sesuai dengan level dan kategori perawat. Dengan adanya jenjang karir professional perawatdi RSBB diharapkan akan memotivasi perawat untuk terus mengembangkan diri dan meningkatkan kualitas pelayanan.

Pengembangan karir perawat merupakan harapan setiap perawat dan dapat meningkatkan kinerja dan kepuasan 
kerja $(13,16,17)$. Oleh karena itu Rumah Sakit Baptis Batu diharapkan dapat melaksanakan pengembangan karir profesional perawat berdasarkan kompetensi $n$ pengetahuan dan ketrampilan untuk mencapai dan diikuti

\section{DAFTAR PUSTAKA}

1. Azwir, Ayuningtyas D, dan Riastuti K. Pengembangan Pola Karir Perawat Klinik Rumah Sakit Umum Daerah Tarakan Jakarta Pusat Tahun 2008. Jurnal Manajemen Pelayanan Kesehatan. 2010; 13(01): 16-22.

2. The Joint Commision. Robert Wood Johnson Foundation Initiative on the Future of Nursing. (Online) 2010. http://www.iom.edu/ / media/Files/Activity\%20Files/Workforce/Nursing/Pr oject\%20Background.pdf

3. Zaidin A. Dasar-Dasar Keperawatan Profesional. Jakarta: Widya Medika; 2001.

4. Kusnanto. Pengantar Profesi \& Praktek Keperawatan Profesional. Jakarta: EGC; 2003.

5. Axley L. Competency: A Concept Analysis. Nursing Forum. 2008; 43(4): 214-222.

6. Furukawa $\mathrm{P}$ and Cunha ICKO. Profile and Competencies of Nurse Managers at Accredited Hospitals. Revista Latino-Am Enfermagem. 2011; 19(1): 106-114.

7. Hayes B, Bonner A, and Pryor J. Factors Contributing to Nurse Job Statisfaction in the Acute Hospital Setting: A Review of Recent Literature. Journal of Nursing Management. 2010; 18(7): 804-814.

8. Hunt ST. Nursing Turnover: Costs, Causes, \& Solutions. USA: SuccessFactors, Inc; 2009.

9. Nault D. Nurse's Essential Role in the Fight for Safe Patient Care. Michigan: Michigan Nurse's Assosiation; 2013. dengan pemberian renumerasi sesuai level dan kategori. Model pengembangan karir yang jelas juga akan mendorong setiap tenaga keperawatan untuk terus meningkatkajenjang karir yang diinginkan.

10. Suroso J. Penataan Sistem Jenjang Karir Berdasarkan Kompetensi untuk Meningkatkan Kepuasan Kerja dan Kinerja Perawat di Rumah Sakit. Explanasi. 2011; 6(2): 123-131.

11. NHS Careers. Careers in Nursing. (Online). http://www.nhscareers.nhs.uk/explore-bycareer/nursing/

12. Nursallam dan Efendy F. Pendidikan dalam Keperawatan. Jakarta: Salemba Medika; 2008.

13. Chanafie D. Hubungan Persepsi Perawat Tentang Jenjang Karir dengan Kepuasan Kerja di RSUD Budhi Asih Jakarta. [Tesis]. Universitas Indonesia, Jakarta. 2005.

14. Kacel B, Miller M, and Norris D. Measurement of Nurse Practitioner Job Satisfaction in a Midwestern State. Journal of American Academy of Nurse Practitioners. 2005; 17(1): 27-32.

15. Iswanty dan Dhini S. Analisis Faktor-faktor yang Berpengaruh terhadap Kepuasan Kerja Tenaga Medis Poliklinik Rawat Jalan RSUD Tugurejo Semarang Tahun 2004. [Tesis]. Universitas Diponegoro, Semarang. 2005.

16. Wibowo F. Analisis Pengaruh Peran Kepemimpinan dan Pengembangan Karir terhadap Komitmen Organisasi dalam Meningkatkan Kinerja Karyawan. [Tesis]. Universitas Diponegoro, Semarang. 2006.

17. Buheli K. Faktor yang Mempengaruhi Kinerja Perawat dalam Penerapan Proses Keperawatan di RSUD Toto Kabupaten Bone Bolango 2012. Beranda. 2012; 5(1). 
Lampiran:

S 2Kep MK 4 tahun $\mathrm{S} 3$ kep MK 1 tahun Kompetensi keperawatan sub spesialis dan konsultan

S 1 kep MK 9 tahun S 2Kep MK 2 tahun $\mathrm{S} 3$ kep MK 0 tahun Kompetensi sub spesialis bimbingan

D III kep MK 9 tahun S 1 Kep MK 6 tahun $\mathrm{S} 2$ kep MK 0 tahun Kompetensi khusus bimbingan

D III kep MK 5 tahun S 1 Kep MK 3 tahun Kompetensi Dasar dibawah bimbingan

D III kep MK 2 tahun S 1 Kep MK 0 tahun Kompetensi Dasar

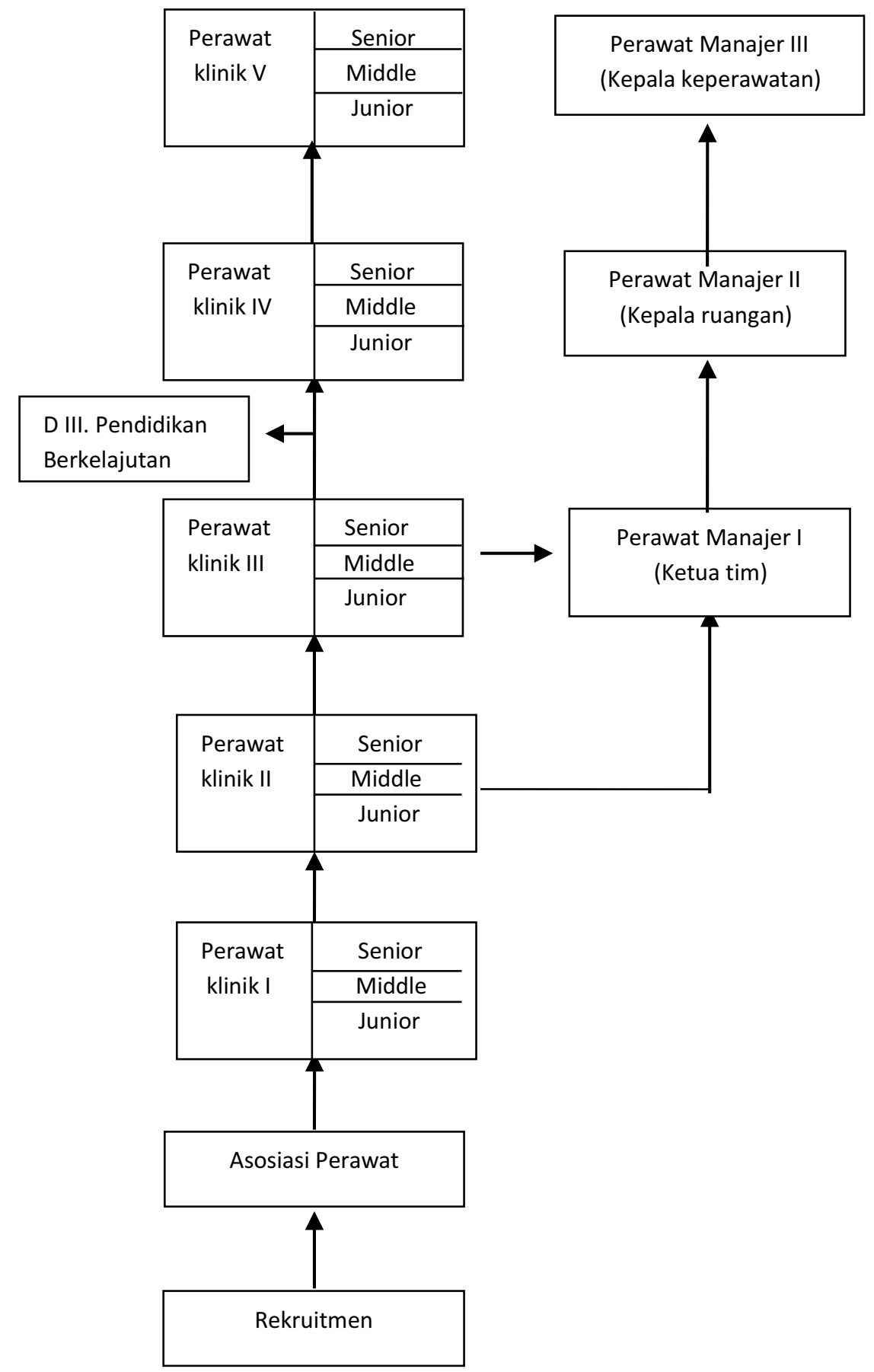

Lampiran. Model Jenjang Karir Perawat Klinis 